\title{
THE USE OF SPIRAL HEAT EXCHANGERS IN THE ORC DOMESTIC SYSTEMS
}

\begin{abstract}
One of the problems encountered while designing the ORC systems is the proper selection of the heat exchangers which depends on many factors. Frequently the shell-tube and plate heat exchangers are mainly used in ORC systems. They can be characterized by low ratio of heat flow to heat transfer surface. It influences the size of the heat exchangers, and furthermore, the amount of the material used and the whole installation expense. Interesting alternative for the currently applied heat exchangers might be Rosenblad's Spiral Heat Exchangers (SHE). What makes this construction so particular is the relatively high ratio of the heat flow to the heat transfer surface. The new design approach dedicated to the Rosenblad's SHE is presented in this article. The formulated method was applied to the calculations of the Rosenblad's SHE, which serves as evaporator in the prototype ORC system. The results of the analysis show that the Rosenblad's SHE is an interesting alternative to other types of the heat exchangers applied presently to the ORC systems. Their application creates a possibility of the reduction of size of the installation, as well as, its expenses.
\end{abstract}

Keywords: spiral heat exchangers, design, ORC, Rosenblad

\section{Introduction}

First spiral heat exchanger was produced in Switzerland by Rosenblad Company in 1932 [7]. Because of many advantages they found wide applications. They are successively applied in paper, petrochemical, food and sugar industries. Important features of spiral heat exchangers are compact design, easy fabrication, high efficiency, small heat losses and low tendency of fouling [2]. Fouling is prevented due to constant change of the direction of the flow, eliminating fluid stagnant zones [10].

In addition, due to geometrical features of this heat exchanger a large heat transfer area is accommodated in relatively small volume [7]. Spiral heat exchangers draw an attention due to its extraordinary construction. Figure 1. pre-

\footnotetext{
${ }^{1}$ Autor do korespondencji/corresponding author: Piotr Kolasiński, Wrocław University of Technology, 27 Wybrzeże Wyspiańskiego Street, 50-370 Wrocław, Poland, tel.: (71) 3202325, e-mail: piotr.kolasinski@pwr.edu.pl

${ }^{2}$ Zbigniew Rogala, Wrocław University of Technology, e-mail: zbigniew.rogala@pwr.edu.pl
} 
sents an isometric view of spiral heat exchanger [8]. Its horizontal cross section is shown in fig. 2. They consist of two long plates rolled together in form of double spiral. Constant spacing between the plates is kept. Upper and lower plates are connected to the spiral part. Such a construction creates two, long, spiral, rectangular channels. Fluid can enter the heat exchanger either through central part or from outermost part. It is common for the hot stream to enter the heat exchanger from the center and leave at the periphery. On the contrary, cold fluid enters the heat exchangers from the outermost part, leaving through the center. Such approach allows minimizing heat losses and increasing heat exchanger's performance. In addition, it means the fluids flow counter-currently. Construction features limits the applicability of spiral heat exchangers. It is not possible to roll the plate thicker than $0.013 \mathrm{~mm}$. It limits the operating pressure to $15 \mathrm{bar}$ [7]. As it was mentioned fluids flow in counter-current. Due to extraordinary geometry of the heat exchanger heat transfer is not purely counter-current flow [1].

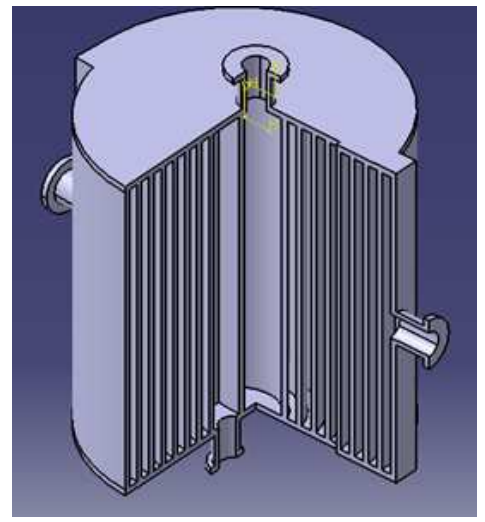

Fig. 1. Isometric view of spiral heat exchanger

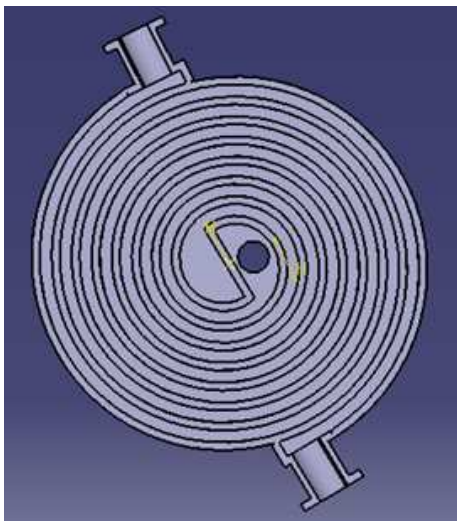

Fig. 2. Cross section of spiral heat exchanger

Hot stream exchanges heat with two adjacent cold streams at different temperatures. The result is temperature driving forces are smaller with respect to classic counter-current flow [7]. Due to wide applicability of spiral heat exchangers plenty of methods of calculation were developed. Design approach of single phase heat transfer, comparing achieved results to case study carried by Minton [5] is developed by Picon-Nunez et al. [7]. Numerical validation indicated sufficient convergence. Bes and Roetzel [1] in their work introduced an analytical rating study for the determination of a temperature profile within the plates. They assumed constant overall heat transfer coefficients. Minton [5] introduced empirical correlations for spiral heat exchangers. Correlations for the heat transfer coefficients and pressure drop were presented. 
In this paper another method of sizing of spiral heat exchangers is presented. Method is dedicated for ORC application and other applications satisfying taken requirements. Presented case concerns more complex heat transfer: heating, evaporation and superheating of R245fa. Presented spiral heat exchanger is dedicated for operating research ORC system as a replacement for shell tube heat exchanger, currently involved as an evaporator.

\section{Mathematical model}

Nowak [6] suggested mathematical model, coherent to describe the processes taking place in spiral heat exchanger. In order to derive these mathematical equations, the element characterized by angle $d \varphi$ (fig. 3.) was established. Following assumptions were taken:

- heat capacities of both mediums are constant,

- heat transfer coefficients are constant,

- the heat is conducted only across the partitions.

a)

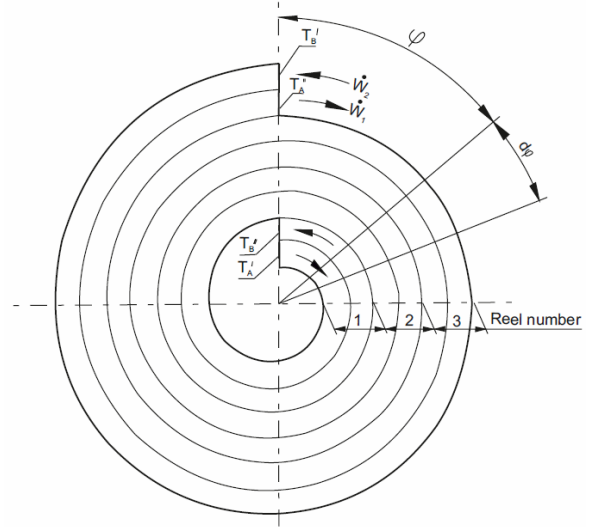

b)

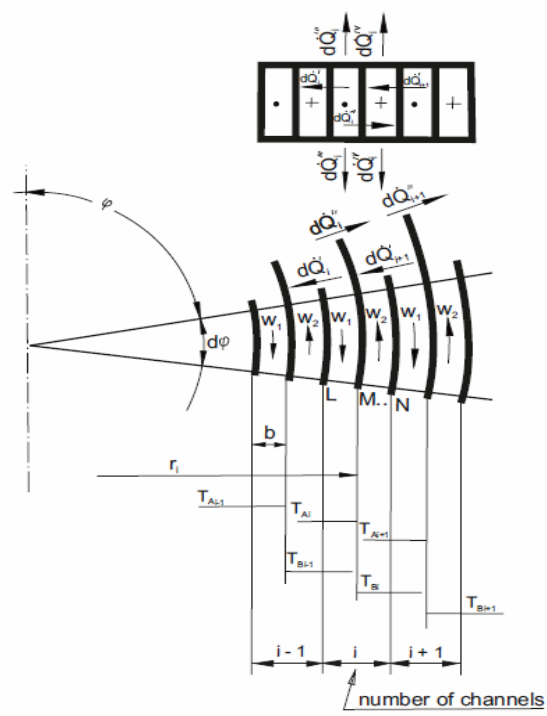

Fig. 3. Mathematical model of spiral heat exchanger: a) general view, b) scheme of the heat transfer

For each scroll following equations describing heat transfer can be established [6]:

- for the hot medium, flowing through the part of the channel, limited by the partitions $\mathrm{L}$ and $\mathrm{M}$ :

$$
\mathrm{d} Q_{i}^{\prime}+\mathrm{d} Q_{i}^{\prime \prime}+\mathrm{d} Q_{i}^{\prime \prime \prime}=-W_{1} \mathrm{~d} T_{A_{i}}
$$


- for cold medium, flowing through the part of the channel, limited by the partitions $\mathrm{N}$ and $\mathrm{M}$ :

$$
\mathrm{d} Q_{i}^{\prime \prime}+\mathrm{d} Q_{i}^{\mathrm{IV}}+\mathrm{d} Q_{i+1}=-W_{2} \mathrm{~d} T_{B_{i}}
$$

Transferred heat is calculated from the following equations:

$$
\begin{aligned}
& \mathrm{d} Q_{i}^{\prime}=k_{z 1-2} h\left(r_{i}-b\right)\left(T_{A_{i}}-T_{B_{i-1}}\right) \mathrm{d} \varphi \\
& \mathrm{d} Q_{i}^{\prime \prime}=k_{z 1-2} h r_{i}\left(T_{A_{i}}-T_{B_{i-1}}\right) \mathrm{d} \varphi \\
& \mathrm{d} Q_{i}^{\prime \prime \prime}=2 k_{z 0-1} b\left(r_{i}-\frac{b}{2}\right)\left(T_{A_{i}}-T_{0}\right) \mathrm{d} \varphi \\
& \mathrm{d} Q_{i}^{\mathrm{IV}}=2 k_{z 2-0} b\left(r_{i}-\frac{b}{2}\right)\left(T_{0}-T_{B_{i}}\right) \mathrm{d} \varphi \\
& \mathrm{d} Q_{i+1}^{\prime}=k_{z 1-2} h\left(r_{i}-b\right)\left(T_{A_{i+1}}-T_{B_{i}}\right) \mathrm{d} \varphi
\end{aligned}
$$

where

$$
r_{i}=r_{0}+2 b(i-1)+\frac{b}{\pi} \varphi .
$$

Equations lead to very complex system of differential equations:

$$
\begin{aligned}
& \frac{\mathrm{d} T_{A_{i}}}{\mathrm{~d} \varphi}+\frac{k_{z 1-2} h}{W_{1}}\left[r_{0}+2 b(i-1)+\frac{b}{\pi} \varphi\right]\left(T_{A_{i}}-T_{B_{i}}\right)+ \\
& +\frac{k_{z 1-2} h}{W_{1}}\left[r_{0}+2 b(i-1)+\left(1-\frac{\varphi}{\pi}\right)\right]\left(T_{A_{i}}-T_{B_{i}}\right)+\frac{2 k_{z 1-0} b}{W_{1}} \\
& {\left[r_{0}+b\left(2 i-\frac{5}{2}\right)+\frac{b}{\pi} \varphi\right]\left(T_{A_{i}}-T_{0}\right)=0} \\
& \frac{\mathrm{d} T_{B_{i}}}{\mathrm{~d} \varphi}+\frac{k_{z 1-2} h}{W_{2}}\left[r_{0}+2 b(i-1)+\frac{b}{\pi} \varphi\right]\left(T_{A_{i}}-T_{B_{i}}\right)+ \\
& +\frac{k_{1-2} h}{W_{2}}\left[r_{0}+2 b(i-1)+\left(1-\frac{\varphi}{\pi}\right)\right]\left(T_{A_{i+1}}-T_{B_{i}}\right)+\frac{2 k_{2-0} b}{W_{2}} \\
& {\left[r_{0}+b\left(2 i-\frac{3}{2}\right)+\frac{b}{\pi} \varphi\right]\left(T_{0}-T_{B_{i}}\right)=0}
\end{aligned}
$$


Solutions suggested by Nowak [6] are very complex and therefore hard to be applied as they require complex matrix calculations.

\section{Exchanger geometry}

Complex study of expressions describing geometry of spiral heat exchanger was published by Dongwu [2]. This work provides equations for spiral diameter, the number of turns and length of semicircles. Nowak [6] also established mathematical tools to express the geometry of spiral heat exchanger. It contains expression for the length of semicircles, the number of turns and area of rolled plates. The aim of geometry calculations is to obtain the length of semicircles. Thus, if other geometry issues are known the area of heat transfer can be calculated:

$$
A_{\text {total }}=\left(l_{s p}-2 r_{0}\right) h
$$

and after solving quadratic equation also the number of scrolls expressed either as an Arabic number:

$$
0=2 b n^{2}+\left(2 r_{0}-b\right) n-\left(r_{0}+\frac{l_{s p}-2 r_{0}}{\pi}\right)
$$

or as an angle of bending:

$$
n_{\mathrm{deg}}=n 360^{\circ}
$$

According to Nowak [6] and Picon-Nunez et al. [7] geometrical dimensions should stay inside following ranges:

- channel width: $b=5-25 \mathrm{~mm}$,

- inner spiral diameter: $r_{0}=150-300 \mathrm{~mm}$,

- outer spiral diameter: $R_{0}=500-2000 \mathrm{~mm}$,

- plate height: $H=100-1800 \mathrm{~mm}$,

- plate thickness: $\rho \geq 13 \mathrm{~mm}$.

\section{Heat transfer description}

Overall heat transfer coefficient is given by:

$$
U=\frac{1}{\frac{1}{h_{1}}+\frac{\rho}{k}+\frac{1}{h_{2}}}
$$


where: $h_{1}, h_{2}$ - convection heat transfer coefficients, $k$ - thermal conductivity of material of construction of the wall.

The heat exchanged through elemental surface $A_{i}$ is given by:

$$
\dot{Q}_{i}=U_{i} A_{i} \Delta T_{i}
$$

where $\Delta T_{i}-$ normal temperature difference for $i$ element.

$\Delta T_{i}$ is given by:

$$
\Delta T_{i}=T_{1, i}-T_{2, i}
$$

where: $T_{1, i}$ - an inlet temperature of stream 1 obtained for element $i, T_{2, i}-$ an inlet temperature of stream 2 obtained for element $i$.

Convection heat transfer coefficients are given by:

$$
h=\frac{\mathrm{Nu} k}{D_{h}}
$$

where: $\mathrm{Nu}$ - Nusselt criterial number, $D_{h}$ - hydraulic diameter.

Hydraulic diameter is given by:

$$
D_{h}=\frac{2 H b}{H+b}
$$

Overall Nusselt number is given by:

$$
\mathrm{Nu}=C \operatorname{Re}^{a} \operatorname{Pr}^{b}
$$

where coefficients $C, a, b$ are dependent on conditions of heat transfer: Reynolds number, shape of the free flow area etc.

Reynolds number is given by:

$$
\operatorname{Re}=\frac{w D_{h}}{v}
$$

where: $w$ - mean velocity of the fluid, $v$-a kinetic viscosity.

Prandtl number is given by:

$$
\operatorname{Pr}=\frac{c_{p} \mu}{k}
$$

where: $c_{p}$ - specific heat, $\mu$-dynamic viscosity. 
Accordingly to Nowak [6], due to additional turbulences during movement around the spiral convection heat transfer coefficient is greater than for the flow through typical straight channel. The coefficient improvement is given by:

$$
h=h_{\text {straight }}\left(1+1,77 \frac{D_{h}}{R_{i}}\right)
$$

where: $h_{\text {straight }}$ - a convection heat transfer coefficient achieved for the same thermodynamic conditions in straight channel, $R_{i}$ - average bending radius for $i$ section.

\section{Design methodology}

Due to the construction of spiral heat exchanger every hot channel (channel filled with hot fluid) is surrounded by two cold channels and vice versa. Such case of heat transfer is very complex. Its solution requires simplifying assumptions. Presented design approach assumes the temperature of the one of the fluids involved in heat transfer remains constant. Such assumption allows considering and solving this case as a simplified case presented in fig. 4.

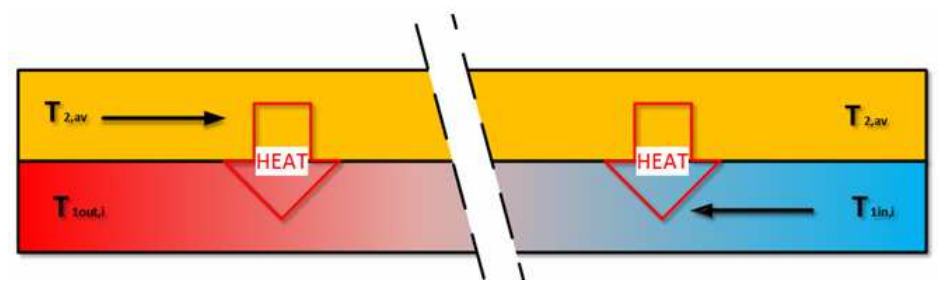

Fig. 4. Simplified heat exchange in spiral heat exchanger

Fluids flow counter-currently in long straight channels. Heat is exchanged through the shared plate. External plates are assumed to be adiabatic. It is assumed that the temperature of one of the fluids is constant. It is recommended to select the fluid characterized by higher specific heat. Its temperature undergoes smaller changes and taken assumption is closer to actual conditions. If one of the fluids undergoes phase transition its temperature remains constant satisfying the assumption. Only selection of the geometry and heat transfer calculations are considered in presented paper. Methodology was completely discussed and described by Rogala [8]. Method is carried as follows:

STEP 1. Selection of the geometry of the spiral heat exchanger. At this point width, height and thickness of the plates and inner spiral diameter have to be selected. Their dimensions are recommended to stay inside suggested ranges. 
STEP 2. In case of complex heat exchange e.g. consisting of preheating, evaporation and superheating each case of heat transfer has to be considered separately.

STEP 3. Preliminary calculations. Usually it is known at once what is the inlet and the desired outlet temperatures or the exchanged heat. Accordingly to this knowledge heat exchange limits are given. Assuming no losses energy balance of heat exchanger is given by:

$$
\dot{m}_{1} c_{p 1}\left(T_{1, \text { in }}-T_{1, \text { out }}\right)=\dot{m}_{2} c_{p 2}\left(T_{2, \text { out }}-T_{2, \text { in }}\right)
$$

where: fluid 1. - heating medium, fluid 2. - heated medium, $\dot{m}_{1}$ and $\dot{m}_{2}$ - mass flow rates respectively of $1^{\text {st }}$ and $2^{\text {nd }}$ fluid.

It is assumed the fluids do not undergo any phase transition during heat transfer.

STEP 4. Establishment of heat transfer surface per section. Performance of the heat exchanger will be calculated for established section's heat transfer surface. The calculations are carried out for every section separately. Assumed quantity of section's heat transfer surface depends on precision we want to achieve.

STEP 5. Heat transfer calculations within the established section. The calculation includes estimation of the temperatures, required thermodynamic parameters etc. Calculation temperature of constant-temperature fluid is given by:

$$
T_{j, a v}=\frac{T_{j, 1}+T_{j, n}}{2}
$$

where: $T_{j, 1}-$ a temperature of the fluid at the beginning of the process, $T_{j, n}-$ a temperature at its end.

The correlations of the fluids' temperatures between adjacent sections are following:

$$
\begin{aligned}
& T_{j \text { in }, i}=T_{j \text { out }, i-1} \\
& T_{j \text { out }, i}=T_{j \text { in }, i+1}
\end{aligned}
$$

Basing on equation difference of temperature is estimated. Further calculations lead to establishment of heat transfer coefficients. At last achieved overall heat transfer coefficient and obtained temperature difference serve to calculate heat exchanged for considered section. The heat is given by:

$$
\dot{Q}_{i}=U_{i} A_{i} \Delta T_{i}
$$


Calculations described in this step are carried until either heat equality is satisfied:

$$
\sum_{i=1}^{n} \dot{Q}_{i} \geq \dot{Q}
$$

where $\dot{Q}$ - overall heat exchanged during the process resulting from energy balance, or temperature equality are satisfied:

$$
T_{\text {jout }, i} \geq T_{\text {jout }}
$$

For heated medium, where $T_{j \text { out }}$ is a temperature resulting from preliminary energy balance:

$$
T_{j \text { out }, i} \leq T_{j \text { out }}
$$

For heating medium, where $T_{j \text { out }}$ is a temperature resulting from preliminary energy balance.

STEP 6. Summary. When the requirements from previous step are satisfied overall surface of heat transfer is summed. Its value is given by:

$$
A_{\text {total }}=\sum_{i=1}^{n} A_{i}
$$

Dongwu [2] suggested an equation for the number of spiral rounds:

$$
N=\frac{-\left(r_{0}-\frac{b}{2}\right)+\sqrt{\left(r_{0}-\frac{b}{2}\right)^{2}+\frac{4 L b}{\pi}}}{2 b}
$$

where $L-$ a length of the spiral.

Heat exchanger consists of two spirals. It is assumed that their length is equal. Therefore the length is given by:

$$
L=\frac{A_{\text {total }}}{2 H}+1
$$

Additional round is suggested to be added because external part of spiral heat exchanger is excluded from heat transfer. In simplified consideration it is involved in the process. Presented methodology neglects heat transfer through other elements than spiral plates. 


\section{Case study}

Proposed methodology of spiral heat exchanger design was applied to design evaporator operating within research ORC system. The simplified scheme of this system is shown in fig. 5. The system is fully described by Kolasiński [4]. Spiral heat exchanger is suggested as a replacement of shell-tube evaporator. Currently operating heat exchanger satisfies successfully its duty, however due to its big dimensions and significant weight it seems to be the most proper solution. It was searched whether current solution can be improved by application of spiral heat exchangers. The algorithm was implemented in Excel. The calculations are semiautomatic. It is necessary to control and extend the calculations personally, however most of them are already prepared. The process can be definitely improved and its application and run can be simplified for the users. The heat exchangers were designed for the stream data shown in tab. 1. Thermodynamic parameters are given as mean values. Working fluid of ORC system is HFC refrigerant R245fa. It is colorless, non-flammable and practically nontoxic. Its technical documentation is included in references [3]. Calculations carried for stream data given in tab. 1 resulted with geometry of spiral heat exchanger shown in tab. 2. Moreover the distribution of temperature along the plate length was established. It is shown in fig. 6. Achieved geometry helps to estimate the space hold and the weight of spiral heat exchanger. It allows to compare these parameters achieved for shell-tube and spiral heat exchangers. This comparison is shown in tab. 3. Application of spiral heat exchanger reduces significantly required surface of heat transfer. Moreover dimensions of the evaporator are decreased greatly (in case of vertical dimension reduction is more than triple). It results in nearly 6 times smaller space hold. However the biggest

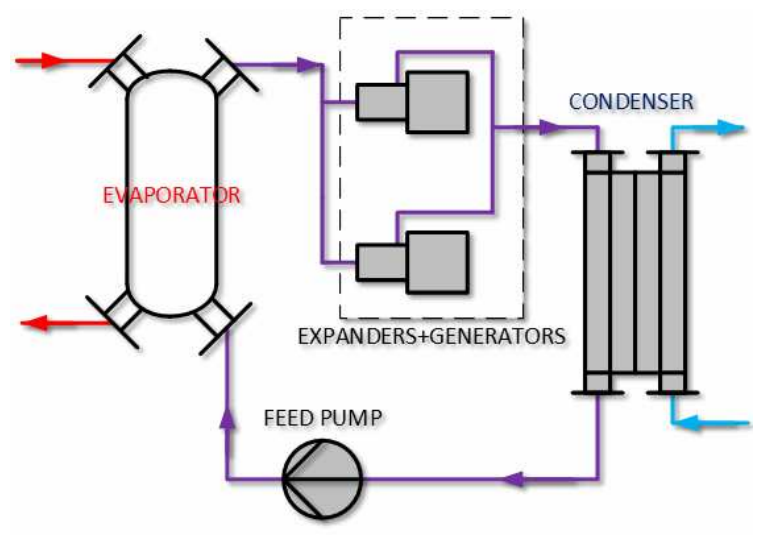

COOLING WATER

HEATING WATER

WORKING FLUID
Fig. 5. Simplified scheme of considered ORC system 
Table 1. Thermodynamic properties of streams

\begin{tabular}{|l|c|c|c|c|}
\hline \multicolumn{1}{|c|}{ Parameter } & Hot stream & $\begin{array}{c}\text { Cold stream } \\
\text { (liquid) }\end{array}$ & $\begin{array}{c}\text { Cold stream } \\
\text { (gas) }\end{array}$ & Unit \\
\hline Flow rate & 0.034 & 0.008 & 0.008 & $\mathrm{~kg} \cdot \mathrm{s}^{-1}$ \\
\hline Inlet temperature & 90 & 20 & - & ${ }^{\circ} \mathrm{C}$ \\
\hline Outlet temperature & 77.1 & - & 87 & ${ }^{\circ} \mathrm{C}$ \\
\hline Pressure & 2 & 6 & 6 & $\mathrm{bar}$ \\
\hline Heat capacity & 4.21 & 1.393 & 1.07 & $\mathrm{~kJ} \cdot \mathrm{kg}^{-1} \cdot \mathrm{K}^{-1}$ \\
\hline Thermal conductivity & 0.672 & 0.087 & 0.018 & $\mathrm{~W} \cdot \mathrm{m}^{-1} \cdot \mathrm{K}^{-1}$ \\
\hline Specific volume & 0.001 & 0.001 & 0.028 & $\mathrm{~m}^{3} \cdot \mathrm{kg}^{-1}$ \\
\hline Viscosity & $4.3 \cdot 10^{-7}$ & $2.9 \cdot 10^{-7}$ & $3.7 \cdot 10^{-7}$ & $\mathrm{~m}^{2} \cdot \mathrm{s}^{-1}$ \\
\hline
\end{tabular}

Table 2. Geometry of the heat exchanger

\begin{tabular}{|l|c|}
\hline Height of the plater, $h$ & $0.2 \mathrm{~m}$ \\
\hline Spacing, $b$ & $0.007 \mathrm{~m}$ \\
\hline Thickness of the plater, $g$ & $0.0006 \mathrm{~m}$ \\
\hline Inner diameter, $r_{0}$ & $0.01 \mathrm{~m}$ \\
\hline Length of the plater, $L$ & $1.625 \mathrm{~m}$ \\
\hline Surface of the plater, $A$ & $0.65 \mathrm{~m}^{2}$ \\
\hline Number of turns, $n$ & 9.14 \\
\hline
\end{tabular}

Table 3. Heat exchangers comparison

\begin{tabular}{|l|c|c|c|}
\hline \multicolumn{1}{|c|}{ Parameter } & Shell-tube [9] & Spiral & Unit \\
\hline Heat transfer surface & 4.9 & 1.3 & $\mathrm{~m}^{2}$ \\
\hline Vertical dimension & 1.05 & 0.272 & $\mathrm{~m}$ \\
\hline Horizontal dimension 1 & 0.416 & 0.35 & $\mathrm{~m}$ \\
\hline Horizontal dimension 2 & 0.416 & 0.35 & $\mathrm{~m}$ \\
\hline Spacehold & 0.1817088 & 0.03332 & $\mathrm{~m}^{3}$ \\
\hline Weight & 55 & 5 & $\mathrm{~kg}$ \\
\hline
\end{tabular}

advantage of the application of spiral heat exchanger is huge reduction of weight: from $55 \mathrm{~kg}$ to only $5 \mathrm{~kg}$. All mentioned advantages make spiral heat exchanger very attractive alternative for already applied heat exchangers. 


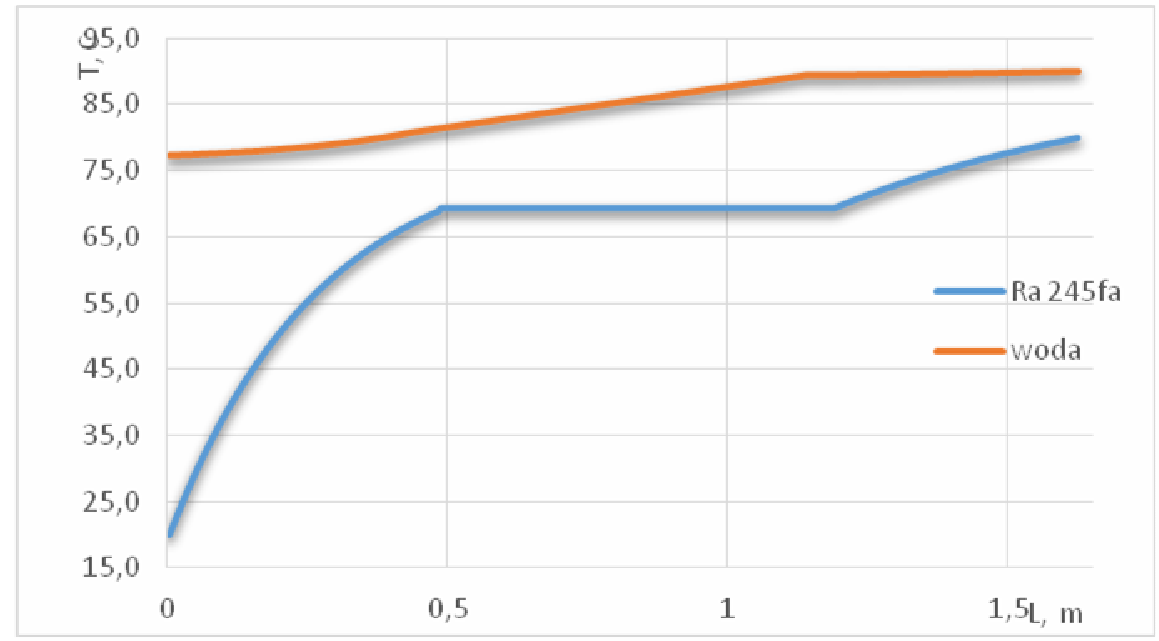

Fig. 6. Temperature distribution in spiral heat exchanger

\section{Conclusions}

New method for the sizing of spiral heat exchangers dedicated for ORC systems has been introduced. Simplification assumes constant temperature of one of the fluids. This assumption corresponds to actual small variation of temperature of the water in considered case. Along the heat exchanger temperature of the water changes from 90 to $77.1^{\circ} \mathrm{C}$. However considering preheating, evaporation and superheating separately changes of water temperature are smaller. Therefore taken assumption seems to be justified. Presented methodology is a basis for preliminary sizing of spiral heat exchangers.

Application of spiral heat exchanger as an evaporator in considered case resulted in significant improvement of heat transfer rate. Spiral heat exchanger outranks shell-tube heat exchanger at any field. Reduction of space hold leads to minimization of size of the facility. Outstanding reduction of weight allows to minimize the costs of materials. Suggested heat exchanger seems to be interesting alternative for currently applied construction.

Summing, presented paper provides only new methodology of design but also indicates applicability of this concept of heat exchanger in Organic Rankin Cycle technologies.

\section{References}

[1] Bes T., Roetzel W.: Distribution of heat flux density in spiral heat exchangers, Int. J. Heat Mass Transfer, 35 (1992), 1331-1347.

[2] Dongwu B.: Geometric calculations of the spiral heat exchangers, Chem. Eng. Technol., 26 (2003), 592-598. 
[3] Honeywell: R245fa Product Stewardship Summary, http://www.honeywell.com.pl/ (dostęp: 9 lipca 2014 r.).

[4] Kolasiński P.: Termodynamika układów konwersji energii o zmiennej ilości czynnika roboczego, Politechnika Wrocławska, Wrocław 2010.

[5] Minton P.E.: Designing spiral heat exchangers, Chem. Eng., 77 (1970), 103-112.

[6] Nowak W.: Teoria rekuperatorów, Wydawn. Uczelniane Politechniki Szczecińskiej, Szczecin 1993.

[7] Picon-Nunez M., Polley G.T., Canizalez-Davalos L., Martinez-Rodriguez G.: Shortcut design approach for spiral heat exchangers, Food Bioproducts Proc., 85 (2007), 322-327.

[8] Rogala Z:: Projekt mikroparowacza Rosenblada do zastosowania w domowych układach ORC, Politechnika Wrocławska, Wrocław 2013.

[9] Secespol Sp. z o.o.: Dokumentacja techniczna wymiennika JAD XK 9.88.08.65.FF, http://secespol.pl/ (dostęp: 9 lipca 2014 r.).

[10] Wilhelmsson W.: Consider spiral heat exchangers for fouling application, Hydrocarbon Proc., 7 (2005), 81-83.

\section{WYKORZYSTANIE SPIRALNYCH WYMIENNIKÓW CIEPŁA W DOMOWYCH UKLADACH ORC}

\section{Streszczenie}

Jednym z problemów występujących podczas projektowania układów ORC jest właściwy wybór wymienników ciepła. Najczęściej stosowanymi rozwiązaniami są wymienniki płaszczowo-rurowe oraz płytowe. Urządzenia te wyróżnia niski współczynnik powierzchni wymiany ciepła do ich objętości. Interesującą alternatywą dla tych konstrukcji mogą być spiralne wymienniki ciepła Rosenblada. Ich konstrukcja zapewnia względnie wysoki wskaźnik przepływu ciepła w odniesieniu do powierzchni wymiany ciepła. Praca prezentuje nową metodę obliczeniową, która jest wykorzystana do projektowania wymienników spiralnych Rosenblada. Opracowana metoda została zastosowana do obliczeń spiralnych wymienników ciepła Rosenblada, które służą jako parowniki prototypowego układu ORC. Na podstawie wyników badań można stwierdzić, że spiralne wymienniki ciepła Rosenblada są interesującą alternatywą dla innych typów wymienników ciepła stosowanych obecnie w układach ORC. Ich zastosowanie stwarza możliwość zmniejszenia rozmiaru instalacji oraz jej kosztu.

Słowa kluczowe: spiralne wymienniki ciepła, projektowanie, ORC, Rosenblad

DOI: $10.7862 / \mathrm{rm} .2015 .3$

Otrzymano/received:15.09.2014 $r$.

Zaakceptowano/accepted:12.03.2015 r. 